\title{
Foreword
}

\section{Thought and Practice: Taking Stock, Re-engaging}

\author{
Thought and Practice: A Journal of the Philosophical Association of Kenya (PAK) \\ Premier Issue, New Series, Vol.1 No.1, June 2009, pp.i-iii \\ thoughtandpractice@uonbi.ac.ke OR thoughtandpractice@gmail.com
}

Jean-Paul Sartre's famous “Orphée noir” (1948) still ranks among the most memorable Prefaces aimed at capturing the significance of the moments of historical regeneration of interrupted cultural expressions. For that piece, simultaneously celebrated and controverted, Sartre borrowed the idea from the ancient Greek religious movement now widely referred to as "Orphism", associated there with the mythical poet or singer, Orpheus, from about the $6^{\text {th }}$. Century B.C.E. The movement led to several mystery cults as well as to a theogony whose key objective was the poetic laudation of the birth, death, and re-birth of the gods. In the original Greek myth, and therefore in the sense that Sartre had hoped to apply to his revaluation of the novel Negritude poetry, the account begins with the idea of "night" as the primal entity from which a series of "kings" or gods springs?.

Needless to say, metaphors are abundant in all the three levels of this "theogonic" resurgence of Thought and Practice in particular, and of the new dawn in the history of African philosophy generally. While the Greek myth depicts the onset of a new historical beginning - a re-awakening of the processes of self-creating acts after a period of lull and despair in Greek culture, Sartre thought that Léopold S. Senghor's inauguration of the new generation of poetry, one that followed an almost decimating effects of colonialism throughout the black world, would similarly set in motion the expressive regeneration of a black culture. Like the gods in the Greek myth, he thought, the poets in Senghor's anthology - Anthologie de la nouvelle poésie nègre et malgache de langue

francaise - become the agents of the new world, a reconfigured historical moment. It is with these ideas in mind that I similarly view the new generation of African philosophers, such as the editors of Thought and Practice to be the agents of a new dawn in the philosophical practice in our country and region. They will have the unenviable, yet so much needed special responsibility, for enabling a re-awakening of minds to grapple with such a much needed discourse. 
ii D.A. Masolo

It will be thirty-five years this year since the first issue of Thought and Practice was published, and much has happened since then. On the good side, African philosophy has attained a measure of autonomy, and has made a visible and significant presence in the global connections between traditions. I was recently invited to give a talk at Indiana University, and I chose to title it "Experience as Philosophical Object: Understanding the Quest in Contemporary African Thought." My view therein was that contemporary African philosophical thought and practice bring to the endeavors of the discipline new ways for revitalizing the connections of philosophical quest with the assumptions that underlie both the orders of everyday beliefs and the structures of social struggles. In another invitation, I claimed, in a "Preface" to the new Encyclopedia of African Thought (being published by Oxford), that intellectual movements are likely to be considered to have attained the status of a tradition partly if they demonstrate the following: have put in place, do recognize, and use, different and basic conceptual tools of self-reference. In that regard, one happily takes note that, besides or in addition to the Encyclopedia of African Thought, the presence in other recent referential texts of a variety of concepts from African philosophical discourses, and names of African philosophers from antiquity to the present, all prove the attainment of this status, while, by the same stroke, opening doors to further debates. I see the significance of the re-launching of Thought and Practice to lie in the role of enabling and advancing this cause. And so, in that sense, for Thought and Practice, the allegorical "night" of Greek mythology is that regrettable period that it shared with several other philosophical periodicals throughout much of the continent, when a combination of factors imposed an unwelcome silence upon our philosophical discourses, causing us to become (like) “zombies”.

May the editors of Thought and Practice remember, and uphold, those standards that alone will make the thinker and writer to give rise, or birth, to new beginnings, to a new dawn, and to a new genealogy of our humanity. A friend, the Cameroonian philosopher Jean-Godefroy Bidima, reminds me that, grounded in palavers, philosophical cogitations are only a special form of "narrating" to each other our stories about those things that we care enough about to want to "palaver" about. They can be any or all of those things that we do or do not like - such as asking, for example, what, why, and on what grounds anything is or should be considered beautiful or ugly, true or false, good 
or bad, nice (pleasant) or unpleasant, and so on. In other words, may our quest embrace and focus on the world of both practical and theoretical reasons in our everyday experiences. Let the new Thought and Practice be a remembrance, and re-affirmation of the ideals of those who first conceived it, especially the name and ideals of Professor Henry Odera Oruka, the Founding Editor of the original Thought and Practice. It would have pleased him deeply that today, African philosophical thinking and practice incorporates what he exemplified in the stories and reflections of the sages. He and his peers from across the continent paved a path that the new generation will now inherit and carefully tend.

\section{D.A. Masolo}

(University of Louisville) 